Check for updates

Cite this: RSC Adv., 2018, 8, 24805

Received 14th May 2018

Accepted 30th June 2018

DOI: $10.1039 / \mathrm{c} 8 \mathrm{ra0} 4081 \mathrm{~h}$

rsc.li/rsc-advances

\section{Co/Cu-MFF derived mesoporous ternary metal oxide microcubes for enhancing the catalytic activity of the $\mathrm{CO}$ oxidation reaction $\uparrow$}

\author{
Huijun Song, ${ }^{\text {abc }}$ Li Zhang, (D) *abcd Guancheng Xu, ${ }^{\text {abc }}$ Chi Zhang, ${ }^{\text {abc }}$ Xin Ma, ${ }^{\text {abc }}$ \\ Lu Zhang ${ }^{\text {abc }}$ and Dianzeng Jia*abc
}

\begin{abstract}
Metal-organic framework (MOF)-based derivatives with uniform micro/mesoporous structures have attracted a great deal of interest in various research fields. Herein, we report a simple strategy to design functional mesoporous ternary metal oxides with controlled composition through direct pyrolysis of Co/Cu bimetalformate frameworks (Co/Cu-MFFs), which were prepared by a facile one-step liquid-phase precipitation method, exhibiting uniform distribution of two different metal species and good structural integrity. The obtained mesoporous ternary metal oxide $\mathrm{Cu}_{x} \mathrm{CO}_{3-x} \mathrm{O}_{4}(x=0.5$, 1) microcubes exhibit much better performance for $\mathrm{CO}$ oxidation than pure $\mathrm{CO}_{3} \mathrm{O}_{4}$, which can be mainly attributed to their larger specific surface areas, stronger reducibility, and the synergistic effect of two active metal oxide components.
\end{abstract}

\section{Introduction}

CO oxidation over solid catalysts has been extensively studied, not only with regard to its value as a classical probe reaction for fundamental studies but also due to its great importance in practical applications, such as air cleanup, gas sensors for detection, automotive exhaust gas treatment and CO elimination from the hydrogen feed for proton-exchange membrane fuel cells. ${ }^{1-5}$ It has been reported that noble metals such as Pt, $\mathrm{Au}$, and $\mathrm{Rh}$ are excellent $\mathrm{CO}$ oxidation catalysts. ${ }^{2,6-11}$ Platinum group metals (PGMs) are some of the earliest catalysts and are still widely employed in automotive emission control and cleaning of gas originating from the petrochemical industry since Langmuir's pioneering work. ${ }^{6,7,12}$ Haruta et al. discovered that oxide-supported Au catalysts prepared through a wet chemistry method exhibit an outstanding high activity for CO oxidation even at cryogenic temperatures..$^{13}$ Recently, a subnano $\mathrm{Rh} / \mathrm{TiO}_{2}$ catalyst with an unexpectedly high performance of total CO conversion at $-50{ }^{\circ} \mathrm{C}$ was discovered by Guan et al. ${ }^{\mathbf{1 0}}$ The excellent properties of this catalyst can be ascribed to the facile formation of $\mathrm{Rh}-\mathrm{O}-\mathrm{O}-\mathrm{Ti}$ superoxide easily reacting with the adsorbed $\mathrm{CO}$ species on $\mathrm{TiO}_{2}$ sites.

${ }^{a}$ Key Laboratory of Energy Materials Chemistry (Xinjiang University), Ministry of Education, Urumqi, Xinjiang, 830046, P. R. China.E-mail: zhanglixju@163.com; jdz0991@gmail.com; Fax: +86-991-8580586; Tel: +86-991-8580586

${ }^{b}$ Key Laboratory of Advanced Functional Materials, Autonomous Region, Urumqi, Xinjiang, 830046, P. R. China

'Institute of Applied Chemistry, Urumqi, Xinjiang, 830046, P. R. China

${ }^{d}$ Physics and Chemistry Detecting Center, Xinjiang University, Urumqi, Xinjiang, 830046, P. R. China

† Electronic supplementary information (ESI) available. See DOI: 10.1039/c8ra04081h
Although these noble metals exhibit high activities for $\mathrm{CO}$ oxidation, the high cost and limited supply constrain their commercial applications. ${ }^{\mathbf{1 4}}$ Thus attention has been focused on searching for "noble metal-free" catalysts with excellent catalytic properties. ${ }^{15-21} \mathrm{Co}_{3} \mathrm{O}_{4}$, one kind of the less-expensive alternatives to the noble metal-based catalysts, has been reported to be one of the most efficient catalysts for carbon monoxide oxidation due to its excellent $\mathrm{CO}$ adsorption strength, low barrier of $\mathrm{CO}$ reacting with lattice $\mathrm{O}$, and remarkable redox properties. ${ }^{14,15,18,22}$ A pioneering work on $\mathrm{Co}_{3} \mathrm{O}_{4}$ for $\mathrm{CO}$ oxidation reported by Xie et al. revealed that the $\mathrm{Co}_{3} \mathrm{O}_{4}$ nanorods demonstrate a catalytic activity towards CO oxidation at a temperature of $-77^{\circ} \mathrm{C} . .^{23}$ The superior performance of the catalyst can be attributed to the predominantly exposed (110) planes with richness of active $\mathrm{Co}^{3+}$ sites. A recent theoretical work found that $\mathrm{Co}^{3+}$ has a higher activity than $\mathrm{Co}^{2+}$ in the $\mathrm{Co}_{3} \mathrm{O}_{4}$ for $\mathrm{CO}$ oxidation because: (i) $\mathrm{Co}^{3+}$ binds $\mathrm{CO}$ molecule strongly compared to $\mathrm{Co}^{2+}$, (ii) a high barrier exists between lattice $\mathrm{O}$ linked to $\mathrm{Co}^{2+}$ and $\mathrm{CO}$ adsorbed on $\mathrm{Co}^{2+} \cdot{ }^{22}$ Therefore, many works are focusing on preparing special nanostructural $\mathrm{Co}_{3} \mathrm{O}_{4}$ predominately exposing active faces with more $\mathrm{Co}^{3+}$ cations to enhance their catalytic activities for $\mathrm{CO}$ oxidation. However, these active faces still contain many $\mathrm{Co}^{2+}$ cations which have lower activities for $\mathrm{CO}$ oxidation. ${ }^{24-26}$ So, replacing the inactive $\mathrm{Co}^{2+}$ with other active divalent cations to prepare Cobased ternary metal oxides provides an efficient way to further enhance the catalytic performance of $\mathrm{Co}_{3} \mathrm{O}_{4}$. On this point, $\mathrm{Cu}^{2+}$ can be a promising candidate for replacing $\mathrm{Co}^{2+}$ in the $\mathrm{Co}_{3} \mathrm{O}_{4}$ not only due to its high activities for $\mathrm{CO}$ oxidation, but also owning to the similar ionic radius with $\mathrm{Co}^{2+}$ which allows the easy formation of $\mathrm{Co} / \mathrm{Cu}$ ternary metal oxides. ${ }^{27-29}$

MOFs are a class of porous functional materials constructed by metal ions and bridging ligands. ${ }^{30-33}$ Owing to its adjustable 
cavities and flexible structures, various metal oxides with specific morphologies and interconnected pores have been fabricated by thermal decomposition of MOFs under suitable calcination conditions, expecting to improve their performance in specific applications. ${ }^{\mathbf{3 4 - 4 2}}$ Among them, ternary metal oxides have gained increasing considerations due to the structure merits and synergetic effect of multiple components. Therefore, bimetallic organic frameworks are considered highly desirable to facile synthesis of the ternary metal oxides. However such effort is still scarce because of the challenge in morphology and composition control during the incorporation of different secondary metal nodes into MOFs. ${ }^{39}$ Divalent metal formate frameworks (MFFs) of $\left[\mathrm{CH}_{3} \mathrm{NH}_{3}\right]\left[\mathrm{M}(\mathrm{HCOO})_{3}\right](\mathrm{M}=\mathrm{Mn}, \mathrm{Fe}, \mathrm{Ni}$, $\mathrm{Co}, \mathrm{Zn})$ could be promising MOFs to tackle this challenge due to the same six-connected $\left(4^{12} \cdot 6^{3}\right)$ nodes of the octahedral $\left(\mathrm{MO}_{6}\right)$ metal ions within the framework. ${ }^{43}$ Herein, we propose a facial one-step synthesis of bimetallic formate frameworks $\left[\mathrm{CH}_{3} \mathrm{NH}_{3}\right]$ $\left[\mathrm{M}(\mathrm{HCOO})_{3}\right](\mathrm{M}=\mathrm{Co} / \mathrm{Cu})(\mathrm{Co} / \mathrm{Cu}-\mathrm{MFFs})$ and its derivation of ternary oxides $\mathrm{Cu}_{x} \mathrm{Co}_{3-x} \mathrm{O}_{4}(x=0,0.5,1,1.5)$ microcubes. The $\mathrm{Cu}_{x} \mathrm{Co}_{3-x} \mathrm{O}_{4}$ microcubes are constructed by numerous interconnected nanoparticles with uniform distribution of cobalt and copper species. In addition, the $\mathrm{Cu} / \mathrm{Co}$ atomic ratio can be controlled exactly through adjusting the compositions of the growth precursor solutions. Owing to its larger specific surface area, stronger reducibility and the synergistic effect of two metal oxide components, the mesoporous $\mathrm{Cu}_{x} \mathrm{Co}_{3-x} \mathrm{O}_{4}$ with moderate $\mathrm{Cu} / \mathrm{Co}$ atomic ratio exhibit better performance for $\mathrm{CO}$ oxidation reaction than pure $\mathrm{Co}_{3} \mathrm{O}_{4}$.

\section{Experimental}

\subsection{Synthesis of $\mathrm{Co} / \mathrm{Cu}-\mathrm{MFFs}$ precursors}

$25 \mathrm{~mL}$ of ethanol was mixed with $12 \mathrm{mmol} \mathrm{HCOOH}, 8 \mathrm{mmol}$ $\mathrm{CH}_{3} \mathrm{NH}_{2}$ (30-33\% in methanol) and $0.5 \mathrm{~g}$ polyvinylpyrrolidone (PVP K-30) to get a colorless solution. Then a transparent solution containing $1 \mathrm{mmol}$ mixed salts with different $\mathrm{Cu} / \mathrm{Co}$ atomic ratios $(0,1: 5,1: 2,1: 1)$ and $0.5 \mathrm{~g}$ PVP K-30 were dropped into the above solution in 10 minutes to obtain a pink colloidal suspension. The whole reaction process was maintained at room temperature with magnetic stirring. One hour later, the colloidal suspension was aged for one day at ambient temperature without any interruption. The resulting pink precipitates were centrifuged and washed several times with ethanol, finally dried at $60{ }^{\circ} \mathrm{C}$ for 6 hours in a vacuum oven and noted as $\left[\mathrm{CH}_{3} \mathrm{NH}_{3}\right]$ $\left[\mathrm{Co}(\mathrm{HCOO})_{3}\right], \quad\left[\mathrm{CH}_{3} \mathrm{NH}_{3}\right]\left[\mathrm{Cu}_{1 / 6} \mathrm{Co}_{5 / 6}(\mathrm{HCOO})_{3}\right], \quad\left[\mathrm{CH}_{3} \mathrm{NH}_{3}\right]\left[\mathrm{Cu}_{1 /}\right.$ $\left.{ }_{3} \mathrm{Co}_{2 / 3}(\mathrm{HCOO})_{3}\right],\left[\mathrm{CH}_{3} \mathrm{NH}_{3}\right]\left[\mathrm{Cu}_{1 / 2} \mathrm{Co}_{1 / 2}(\mathrm{HCOO})_{3}\right]$ respectively.

\subsection{Synthesis of $\mathrm{Cu}_{x} \mathrm{Co}_{3-x} \mathrm{O}_{4}(x=0,0.5,1,1.5)$ microcubes}

The porous ternary metal oxides were fabricated in muffle burner by annealing these prepared $\mathrm{Co} / \mathrm{Cu}-\mathrm{MFFs}$ precursors at $350{ }^{\circ} \mathrm{C}$ for 2 hours, at a heating rate of $1{ }^{\circ} \mathrm{C} \mathrm{min}{ }^{-1}$ and noted as $\mathrm{Co}_{3} \mathrm{O}_{4}, \mathrm{Cu}_{0.5} \mathrm{Co}_{2.5} \mathrm{O}_{4}, \mathrm{CuCo}_{2} \mathrm{O}_{4}, \mathrm{Cu}_{1.5} \mathrm{Co}_{1.5} \mathrm{O}_{4}$, respectively.

\subsection{Characterizations}

Powder XRD patterns were recorded on a Bruker D8 advance diffractometer with $\mathrm{Cu} \mathrm{K}$ radiation over the $2 \theta$ range of $10-80^{\circ}$.
Thermogravimetric analyses (TGA) were carried out in a Netzsch SDT449F3 thermal analyzer in air atmosphere with a heating rate of $5{ }^{\circ} \mathrm{C} \mathrm{min}^{-1}$. The SEM and TEM images of the prepared samples were obtained through field emission scanning electron microscopy (FESEM, Hitachi S-4800 microscope) and transmission electron microscopy (TEM, JEOL, JEM-2100F). The chemical composition and elemental distribution of the prepared catalysts were examined by Energy-dispersive X-ray spectroscope (EDX) attached to the FESEM instrument. ICP-OES was used to determine the $\mathrm{Cu} / \mathrm{Co}$ atomic ratio of $\mathrm{Cu}_{x} \mathrm{Co}_{3-x} \mathrm{O}_{4}$. The X-ray photoelectron spectroscopy (XPS) spectra were collected on Thermo ESCALAB $250 \mathrm{Xi}$ spectrometer. $\mathrm{N}_{2}$ adsorption-desorption isotherm were obtained by a Micromeritics ASAP 2020 analyzer at $77 \mathrm{~K} . ~_{\mathrm{H}_{2}}$ temperature-programmed reduction $\left(\mathrm{H}_{2}\right.$-TPR) experiments were performed under a $10 \mathrm{vol} \% \mathrm{H}_{2} / \mathrm{Ar}$ mixture with a flow rate of 50 $\mathrm{mL} \min ^{-1}$ over $60 \mathrm{mg}$ of catalyst by a Micromeritics Chemisorb 2920 apparatus and the temperature was increased from ambient temperature to $800{ }^{\circ} \mathrm{C}$ at a ramp rate of $1{ }^{\circ} \mathrm{C} \mathrm{min}{ }^{-1}$. Prior to each analysis, the catalysts were purged in a flow of pure argon at $200{ }^{\circ} \mathrm{C}$ for 2 hours to remove traces water.

\subsection{Catalytic performance measurements}

The catalytic tests of the $\mathrm{Cu}_{x} \mathrm{Co}_{3-x} \mathrm{O}_{4}$ microcubes for $\mathrm{CO}$ oxidation reaction were performed in a fixed quartz tubular reactor. The reactor was charged with $50 \mathrm{mg}$ of the catalysts without pretreatment. The reaction temperature was detected by a thermocouple under catalyst bed. The mixed feed gas consisted of $1 \mathrm{vol} \% \mathrm{CO}, 20 \mathrm{vol} \% \mathrm{O}_{2}, 79 \mathrm{vol} \% \mathrm{~N}_{2}$ was passed through the

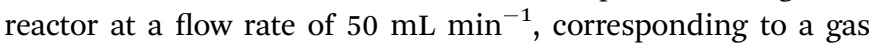
hourly space velocity (GHSV) of $60000 \mathrm{~mL} \mathrm{~g}^{-1} \mathrm{~h}^{-1}$. The components of the gas were examined by a gas chromatograph (Agilent GC7890). Two catalytic test data points at each temperature were collected and the average values of them were reported.

\section{Results and discussion}

The synthesis process of mesoporous $\mathrm{Cu}_{x} \mathrm{Co}_{3-x} \mathrm{O}_{4}$ microcubes is shown in Scheme 1. Firstly, the Co/Cu-MFFs precursors with different $\mathrm{Cu} / \mathrm{Co}$ atomic ratios were synthesized through a onestep liquid-phase precipitation method under room temperature. Then, the $\mathrm{Cu}_{x} \mathrm{Co}_{3-x} \mathrm{O}_{4}$ microcubes with porous structure were obtained through thermal decomposition of the precursors under air. The phase and purity of the Co/Cu-MFFs precursors and $\mathrm{Cu}_{x} \mathrm{Co}_{3-x} \mathrm{O}_{4}$ were examined by PXRD (Fig. 1a). All strong peaks in the XRD patterns of each Co/Cu-MFFs

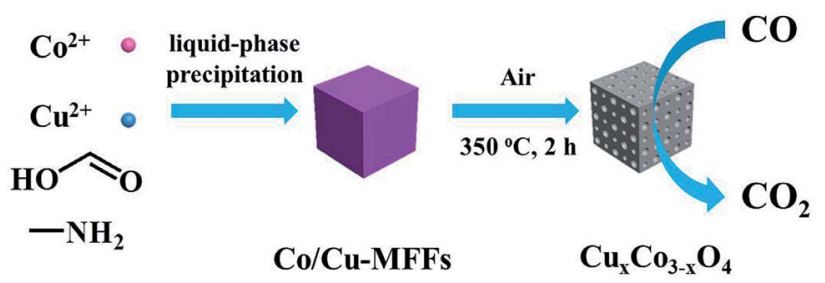

Scheme 1 Schematic illustration of the synthesis of Co/Cu-MFFs precursors and its derived mesoporous $\mathrm{Cu}_{x} \mathrm{CO}_{3-x} \mathrm{O}_{4}$ microcubes for CO oxidation reaction 

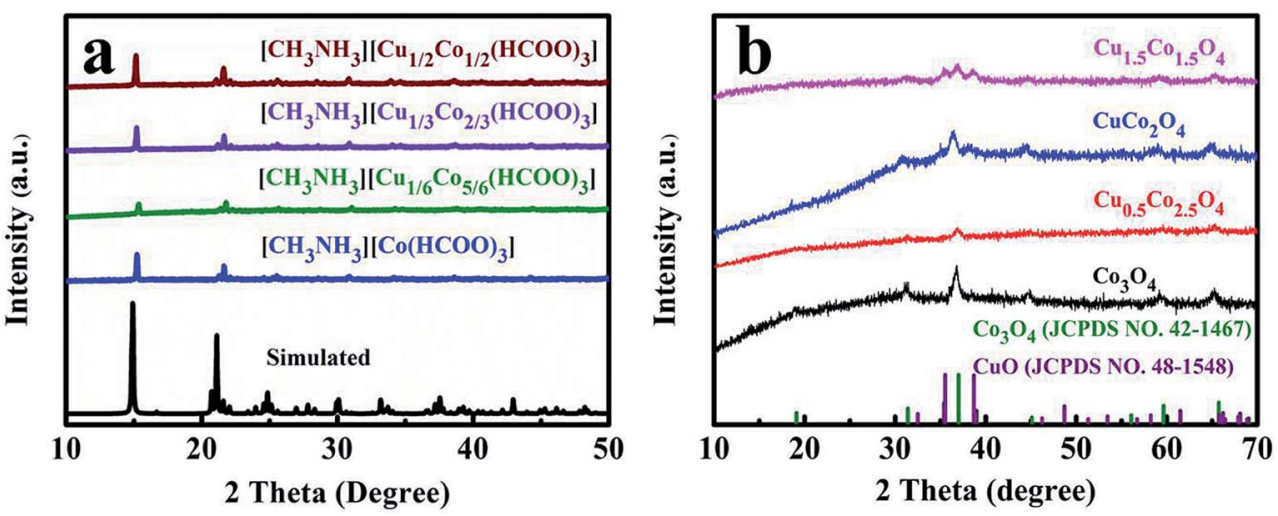

Fig. 1 XRD patterns of $\mathrm{Co} / \mathrm{Cu}$-MFFs precursors (a) and $\mathrm{Cu}_{x} \mathrm{CO}_{3-x} \mathrm{O}_{4}$ microcubes (b).

precursor are well matched with the simulated single crystal structure of $\left[\mathrm{CH}_{3} \mathrm{NH}_{3}\right]\left[\mathrm{Co}(\mathrm{HCOO})_{3}\right]$ according to the reported crystal structure data, ${ }^{44,45}$ suggesting the successful incorporation of $\mathrm{Cu}^{2+}$ into Co/Cu-MFFs. Fig. S1† shows the TGA curves of as-prepared precursors, indicating that the weight residual of all samples becomes constant when the temperature rises to $300^{\circ} \mathrm{C}$. During the calcination, all samples exhibit similar twostep weight loss. The first weight loss could be relate to the removal of amine and one formate molecule per formula unit. The second weight loss could be due to the decomposition of residual organic components. Fig. $1 \mathrm{~b}$ shows that the corresponding diffraction profiles of prepared ternary oxides $\mathrm{Cu}_{x}{ }^{-}$ $\mathrm{Co}_{3-x} \mathrm{O}_{4}$ are in agreement with the standard $\mathrm{CuCo}_{2} \mathrm{O}_{4}$ (JCPDS no. 01-1155) or pure $\mathrm{Co}_{3} \mathrm{O}_{4}$ (JCPDS no. 42-1467). $\mathrm{CuCo}_{2} \mathrm{O}_{4}$ can be treated as $\mathrm{Co}_{3} \mathrm{O}_{4}$ with $\mathrm{Co}^{2+}$ replaced by $\mathrm{Cu}^{2+}$ and therefore these two oxides have almost same XRD patterns. Meanwhile, two weak peaks corresponding to $\mathrm{CuO}$ (002), (111) (JCPDS no. 48-1548) can be seen in the XRD patterns of $\mathrm{CuCo}_{2} \mathrm{O}_{4}$ and $\mathrm{Cu}_{1.5} \mathrm{Co}_{1.5} \mathrm{O}_{4}$, suggesting that a few $\mathrm{Cu}^{2+}$ cations did not enter into the lattice of $\mathrm{Co}_{3} \mathrm{O}_{4}$ successfully. These two peaks become obvious with the increase of $\mathrm{Cu}$-doping amount, indicating that the excess amounts of $\mathrm{Cu}^{2+}$ cations in the $\mathrm{Co} / \mathrm{Cu}$-MFFs precursors lead to a significant phase segregation of the oxides.

The SEM images in Fig. S2a and S2b $\dagger$ reveal that the asprepared $\left[\mathrm{CH}_{3} \mathrm{NH}_{3}\right]\left[\mathrm{Co}(\mathrm{HCOO})_{3}\right]$ and $\left[\mathrm{CH}_{3} \mathrm{NH}_{3}\right]\left[\mathrm{Cu}_{1 / 3} \mathrm{Co}_{2 /}\right.$ $\left.{ }_{3}(\mathrm{HCOO})_{3}\right]$ have similar cubic shapes with smooth surfaces and some macropores about $0.6 \mu \mathrm{m}$ can be observed clearly on the partial surfaces of these two precursors. Meanwhile, the size of $\left[\mathrm{CH}_{3} \mathrm{NH}_{3}\right]\left[\mathrm{Cu}_{1 / 3} \mathrm{Co}_{2 / 3}(\mathrm{HCOO})_{3}\right]$ microcubes is about 1-2 $\mu \mathrm{m}$, which is smaller than that of $\left[\mathrm{CH}_{3} \mathrm{NH}_{3}\right]\left[\mathrm{Co}(\mathrm{HCOO})_{3}\right]$, mainly about $2-3 \mu \mathrm{m}$. We can infer accordingly that the introduced $\mathrm{Cu}^{2+}$ does not have great influences on the morphology of precursors. In order to study the effect of PVP K-30 in the preparation of $\mathrm{Co} / \mathrm{Cu}-\mathrm{MFFs}$ precursors, the morphology of $\left[\mathrm{CH}_{3} \mathrm{NH}_{3}\right]\left[\mathrm{Co}(\mathrm{HCOO})_{3}\right]$ prepared in the absence of PVP K-30 was also characterized. As shown in Fig. $\mathrm{S} 3, \uparrow$ the $\left[\mathrm{CH}_{3} \mathrm{NH}_{3}\right]$ $\left[\mathrm{Co}(\mathrm{HCOO})_{3}\right]$ without adding PVP K-30 still retains the cubic morphology but many microbes agglomerate together. So we can infer that PVP K-30 functions here mainly as stabilizing agent to prevent agglomeration of the microcubes. The similar functions have been reported by many other reports. ${ }^{46,47}$ The
SEM images of $\mathrm{Cu}_{x} \mathrm{Co}_{3-x} \mathrm{O}_{4}$ easily prepared by annealing precursors are shown in Fig. 2a-d. The cubic morphology of $\mathrm{Cu}_{x} \mathrm{Co}_{3-x} \mathrm{O}_{4}$ reveals that all the $\mathrm{Cu}_{x} \mathrm{Co}_{3-x} \mathrm{O}_{4}$ almost preserved the original cubic morphology of as-prepared precursors. Meanwhile, a great number of small nanoparticles on the rough surface of cubic $\mathrm{Cu}_{x} \mathrm{Co}_{3-x} \mathrm{O}_{4}$ can be seen clearly in the SEM images, which confirms the successful formation of porous structure. The chemical composition and elemental distribution of the microcubes were further characterized by SEM-EDX. The elemental mapping images (Fig. 2e and S4†) further confirm that all the ternary metal oxides are with similar microcubic morphologies and the uniform distribution of $\mathrm{O}, \mathrm{Cu}$ and $\mathrm{Co}$. The metal element ratios of $\mathrm{Cu}$ and $\mathrm{Co}$ in the oxides are similar with those ratios in the growth precursor solution as shown in Table S1 and Fig. S5, $\dagger$ which shows that the compositions of $\mathrm{Cu}_{x} \mathrm{Co}_{3-x} \mathrm{O}_{4}$ can be controlled exactly by adjusting the synthesis of $\left[\mathrm{CH}_{3} \mathrm{NH}_{3}\right]\left[\mathrm{Cu}_{1 / 3} \mathrm{Co}_{2 / 3}(\mathrm{HCOO})_{3}\right]$. The high-resolution TEM image of $\mathrm{CuCo}_{2} \mathrm{O}_{4}$ microcube is shown in Fig. 2f, the interplanar distances of $0.23 \mathrm{~nm}$ can be indexed to the (111) plane of $\mathrm{CuO}$, whereas the interplanar distance of $0.24 \mathrm{~nm}$ is correspondence to the (311) plane of $\mathrm{CuCo}_{2} \mathrm{O}_{4}$. The interlaced boundaries marked with white circle demonstrate the high interdispersion of the $\mathrm{CuO}$ and $\mathrm{CuCo}_{2} \mathrm{O}_{4}$.

Some related mechanisms at the molecular level of $\mathrm{Co}_{3} \mathrm{O}_{4}$ for $\mathrm{CO}$ oxidation suggest that gas phase $\mathrm{CO}$ chemisorbs preferably on the exposed $\mathrm{Co}^{3+}$, then reacts with an oxygen atom linked to the active $\mathrm{Co}^{3+}$ site resulting in $\mathrm{CO}_{2}$ and an oxygen vacancy formation. ${ }^{24,48}$ Therefore, the amount of the exposed $\mathrm{Co}^{3+}$ cations on the $\mathrm{Co}_{3} \mathrm{O}_{4}$ surfaces is responsible for catalytic activity. ${ }^{49}$ Herein, the XPS analysis was further carried out to examine the surface chemical compositions and elemental states of $\mathrm{Cu}_{x} \mathrm{Co}_{3-x} \mathrm{O}_{4}$ microcubes. The Co2p XPS spectra profiles (Fig. 3a) constructed with two main peaks centering at about 779.5 and $794.6 \mathrm{eV}$, corresponding to the $\mathrm{Co} 2 \mathrm{p}_{3 / 2}$ and Co2 $\mathrm{p}_{1 / 2}$ respectively. ${ }^{37,50,51}$ The relative percentage of $\mathrm{Co}^{3+}$ and $\mathrm{Co}^{2+}$ was calculated through the fitted curves of $\mathrm{Cu}_{x} \mathrm{Co}_{3-x} \mathrm{O}_{4}$, and was plotted as functions of the $\mathrm{Cu} / \mathrm{Co}$ atomic ratio in the solution of preparing precursors (Fig. 3b). We can find that the ratio of $\mathrm{Co}^{2+/} \mathrm{Co}^{3+}$ on the surface of $\mathrm{Cu}_{x} \mathrm{Co}_{3-x} \mathrm{O}_{4}$ first drastically decreases and then almost remains unchanged with the increasing $\mathrm{Cu} / \mathrm{Co}$ atomic ratio. That decline of $\mathrm{Co}^{2+} / \mathrm{Co}^{3+}$ atomic 

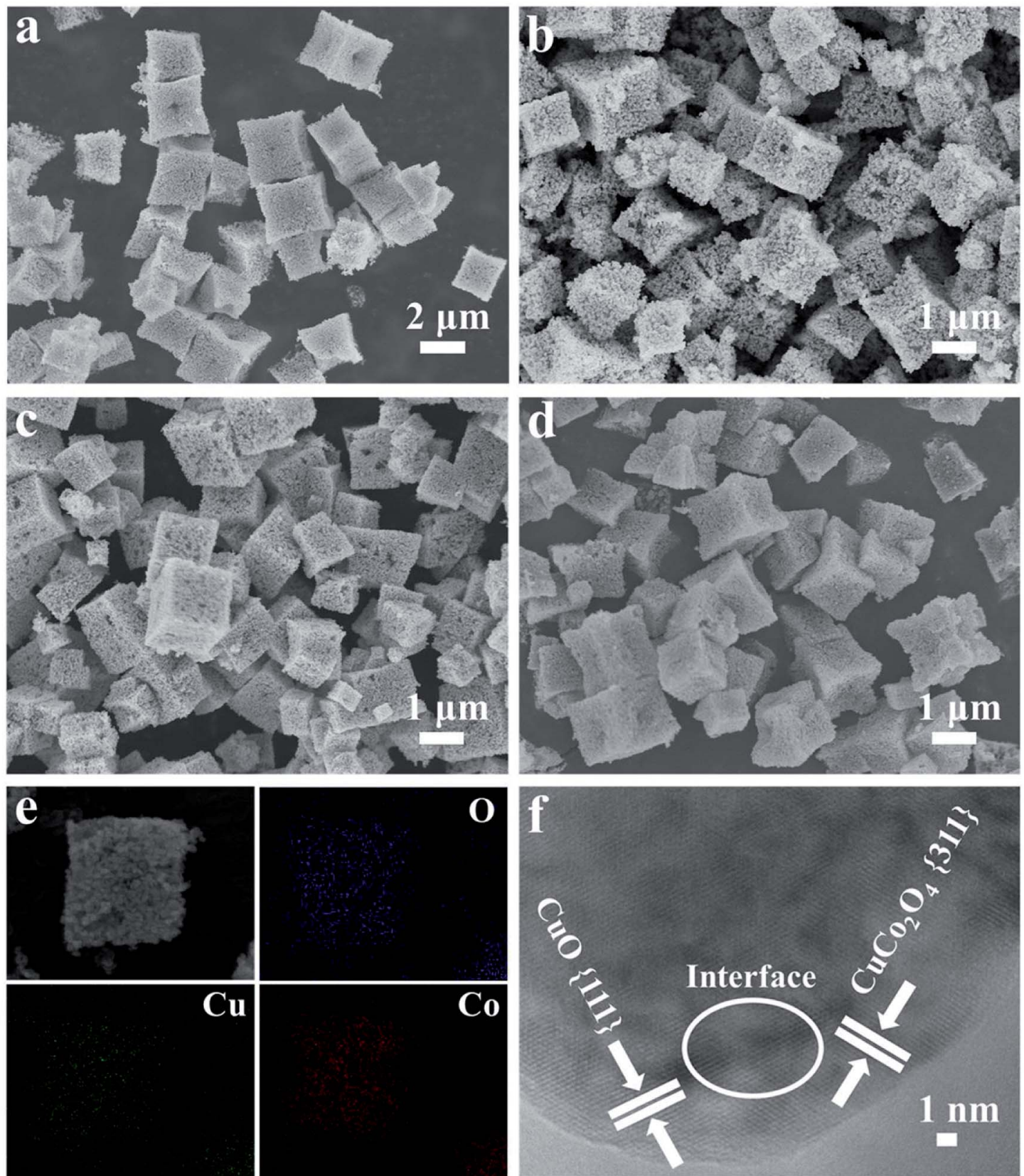

Fig. 2 SEM images of $\mathrm{CO}_{3} \mathrm{O}_{4}$ (a), $\mathrm{Cu}_{0.5} \mathrm{CO}_{2.5} \mathrm{O}_{4}$ (b), $\mathrm{CuCO}_{2} \mathrm{O}_{4}$ (c), $\mathrm{Cu}_{1.5} \mathrm{Co}_{1.5} \mathrm{O}_{4}$ (d), SEM-EDX mapping images of $\mathrm{CuCO}_{2} \mathrm{O}_{4}$ (e), TEM images of $\mathrm{CuCO}_{2} \mathrm{O}_{4}$ (f).

ratio should be originated from the $\mathrm{Cu}^{2+}$ substitution for $\mathrm{Co}^{2+}$ in $\mathrm{Cu}_{x} \mathrm{Co}_{3-x} \mathrm{O}_{4}$. The further steadiness might be ascribed to many $\mathrm{Cu}^{2+}$ leading to the formation of $\mathrm{CuO}$ rather than substitution for $\mathrm{Co}^{2+}$, which can also be inferred from the XRD results.

The porous structures of $\mathrm{Co} / \mathrm{Cu}-\mathrm{MFFs}$ derived $\mathrm{CuCo}_{2} \mathrm{O}_{4}$ and pure $\mathrm{Co}_{3} \mathrm{O}_{4}$ were further examined by measuring sorption isotherms of nitrogen at $77 \mathrm{~K}$. It can be observed in Fig. $4 \mathrm{a}$ that both of the oxides present a type-IV adsorption isotherm with a significant hysteresis loop, denoting that they are mesoporous solids. The specific surface areas of $\mathrm{Co}_{3} \mathrm{O}_{4}$ and $\mathrm{CuCo}_{2} \mathrm{O}_{4}$ microcubes were calculated to be 25.59 and $29.47 \mathrm{~m}^{2} \mathrm{~g}^{-1}$ through Brunauer-Emmett-Teller (BET) method. In addition, the corresponding Barrett-Joyner-Halenda (BJH) pore size distribution plots (Fig. S6 $\dagger$ ) show the main pore size distribution of $\mathrm{Co}_{3} \mathrm{O}_{4}$ and $\mathrm{CuCo}_{2} \mathrm{O}_{4}$ are 0.71-1.58 nm and 16.15$20.73 \mathrm{~nm}$, respectively.

To directly evaluate the catalytic performance of the $\mathrm{Co} / \mathrm{Cu}-$ MFFs derived ternary oxides for $\mathrm{CO}$ oxidation reaction, $50 \mathrm{mg}$ of the mesoporous $\mathrm{Cu}_{x} \mathrm{Co}_{3-x} \mathrm{O}_{4}$ microcubes without any pretreatments were put into a fixed quartz glass reactor respectively. As shown in Fig. 4b, with the increasing amount of $\mathrm{Cu} / \mathrm{Co}$ atomic ratio in the catalysts, the catalytic activities of $\mathrm{Cu}_{x^{-}}$ $\mathrm{Co}_{3-x} \mathrm{O}_{4}$ for $\mathrm{CO}$ oxidation reaction firstly increase and then decrease. Among them, $\mathrm{CuCo}_{2} \mathrm{O}_{4}$ exhibits the highest activity 

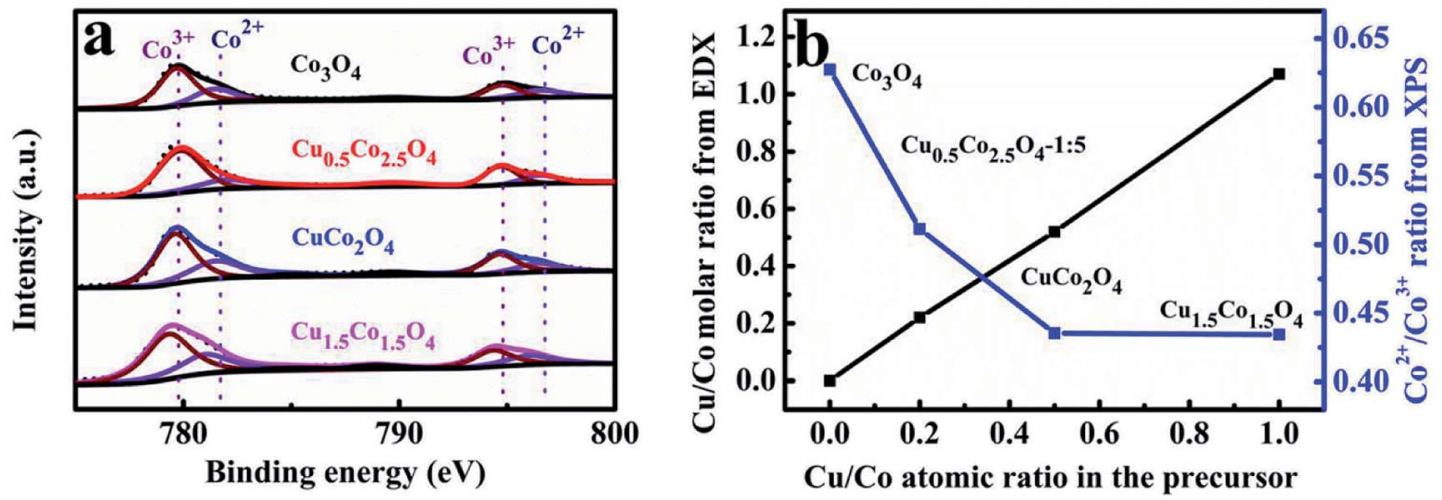

Fig. 3 XPS spectra of the $\mathrm{Cu}_{x} \mathrm{CO}_{3-x} \mathrm{O}_{4}$ microcubes (a), the measured $\mathrm{Cu} / \mathrm{Co}$ atomic ratio and $\mathrm{Co}^{2+} / \mathrm{Co}^{3+}$ atomic ratio on the surface of the $\mathrm{Cu}_{x} \mathrm{CO}_{3-x} \mathrm{O}_{4}$ microcubes as functions of the $\mathrm{Cu} / \mathrm{Co}$ atomic ratio in the solution of preparing precursors (b).

with $100 \% \mathrm{CO}$ conversion rate at $120^{\circ} \mathrm{C}$, superior or comparable to other transition oxides as $\mathrm{CO}$ oxidation catalysts (Table $\mathrm{S} 2 \dagger$ ). These results indicate that using more active $\mathrm{Cu}^{2+}$ to replace the inactive $\mathrm{Co}^{2+}$ in the lattice of $\mathrm{Co}_{3} \mathrm{O}_{4}$ could be a novel way to enhance the catalytic performance for $\mathrm{CO}$ oxidation. Meanwhile, the $\mathrm{Cu}_{1.5} \mathrm{Co}_{1.5} \mathrm{O}_{4}$ has the lowest activity and the temperature of $\mathrm{CO}$ complete conversion is as high as $170{ }^{\circ} \mathrm{C}$, which might be due to the richness of less-active $\mathrm{CuO}$ phase. The $\mathrm{CO}$ oxidation conversions of without materials and with $50 \mathrm{mg}$ of precursors performed under different temperatures were shown in Fig. $\mathrm{S} 7, \dagger$ the results indicated that there was no catalytic activity in the absence of catalyst and the Co/Cu-MFFs exhibited extremely low catalytic activity of $\mathrm{CO}$ oxidation. We also investigated the stabilities of pure $\mathrm{Co}_{3} \mathrm{O}_{4}$ and $\mathrm{CuCo}_{2} \mathrm{O}_{4}$ under the similar conditions at 140 and $130{ }^{\circ} \mathrm{C}$, respectively (Fig. 4c). Both samples exhibit good stable performance that retains CO complete conversion within 30 hours. Based on these results, we can infer that the enhanced catalytic activity of $\mathrm{Cu}_{x} \mathrm{Co}_{3-x} \mathrm{O}_{4}$ can be attributed to the structure and component merits achieved through the incorporation of new secondary copper nodes
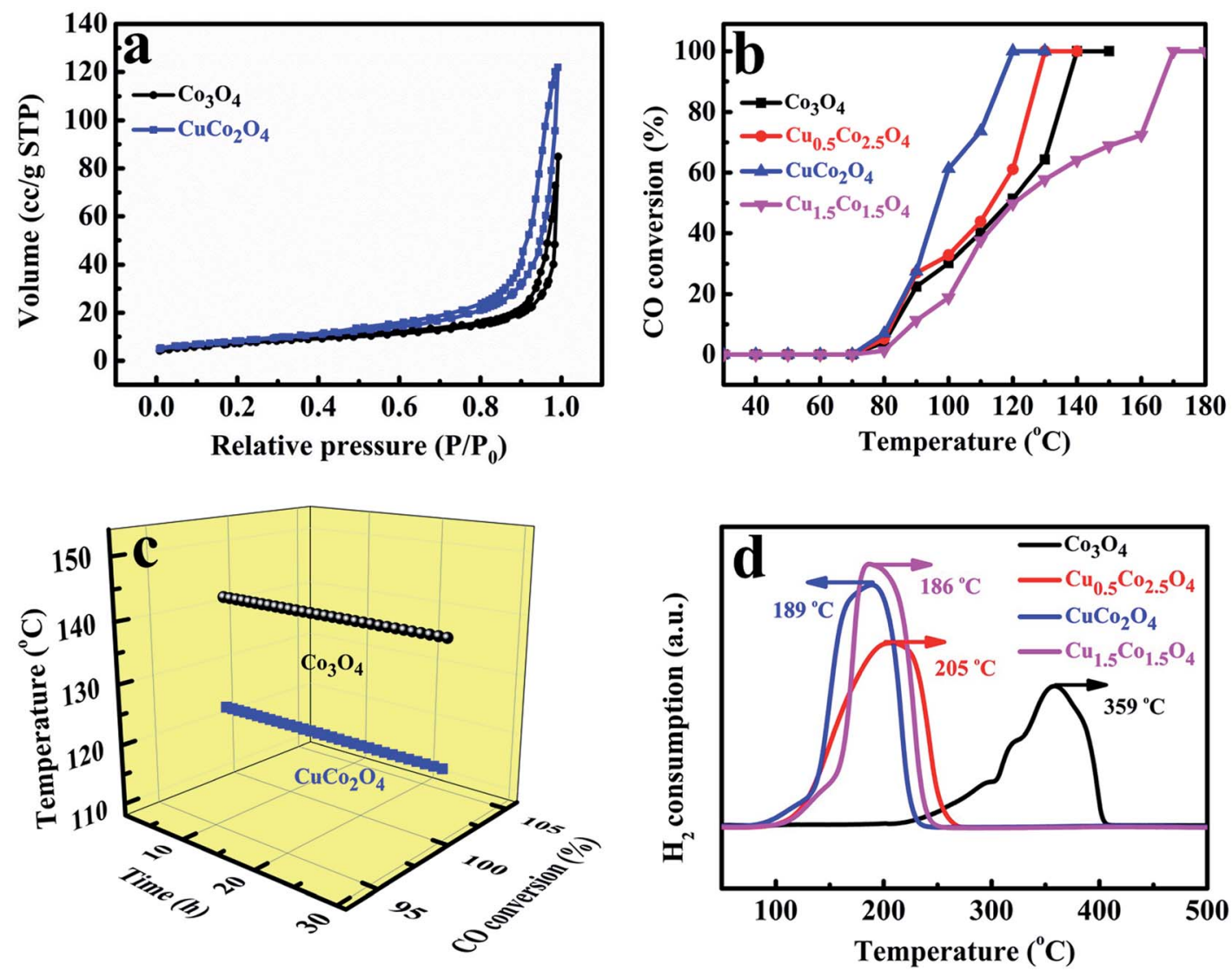

Fig. 4 Nitrogen adsorption-desorption isotherms of $\mathrm{Co}_{3} \mathrm{O}_{4}$ and $\mathrm{CuCO}_{2} \mathrm{O}_{4}$ (a), the catalytic activities of $\mathrm{Cu}_{x} \mathrm{CO}_{3-x} \mathrm{O}_{4}$ for $\mathrm{CO}_{3}$ oxidation (b), stability of $\mathrm{CO}_{3} \mathrm{O}_{4}$ at $140{ }^{\circ} \mathrm{C}$ and $\mathrm{CuCO}_{2} \mathrm{O}_{4}$ at $120{ }^{\circ} \mathrm{C}$ (c), $\mathrm{H}_{2}$-TPR profiles of $\mathrm{Cu}_{x} \mathrm{CO}_{3-x} \mathrm{O}_{4}$ (d). 
in the $\mathrm{Co} / \mathrm{Cu}$-MFFs precursors. In addition, pure $\mathrm{Co}_{3} \mathrm{O}_{4}$ presents a good activity for $\mathrm{CO}$ oxidation with a $\mathrm{CO}$ complete conversion temperature of $140{ }^{\circ} \mathrm{C}$, which is $30{ }^{\circ} \mathrm{C}$ lower than that reported by Zhang et $a .^{52}$ The higher catalytic activity might be ascribed to the larger specific surface area and the lower inactive $\mathrm{Co}^{2+}$ concentration in the surface of $\mathrm{Co}_{3} \mathrm{O}_{4}$ according to the BET and XPS results (Table $\mathrm{S} 3 \dagger){ }^{52}$

To further investigate the synergetic effects of $\mathrm{Cu}$ and $\mathrm{Co}$ species, the temperature-programmed reductions were performed using a stream of diluted $\mathrm{H}_{2}\left(\mathrm{H}_{2} / \mathrm{Ar}_{2}, 1: 9 \mathrm{v} / \mathrm{v}\right)$. As shown in Fig. $4 \mathrm{~d}$, only a single peak at $359{ }^{\circ} \mathrm{C}$ is observed in pure $\mathrm{Co}_{3} \mathrm{O}_{4}$ microcubes reduction profile, which can be explained by the direct reduction of cobalt ions into metallic Co in one step for the large particles of $\mathrm{Co}_{3} \mathrm{O}_{4} \cdot{ }^{53}$ With the amount of $\mathrm{Cu}^{2+}$ increasing in catalysts, the prominent peaks of $\mathrm{Cu}_{0.5} \mathrm{Co}_{2.5} \mathrm{O}_{4}, \mathrm{CuCo}_{2} \mathrm{O}_{4}$ and $\mathrm{Cu}_{1.5} \mathrm{Co}_{1.5} \mathrm{O}_{4}$ shift towards lower temperature to 205,189 and $186{ }^{\circ} \mathrm{C}$, respectively, which means that the reducibility of the catalysts was markedly promoted when the $\mathrm{Cu} / \mathrm{Co}$ atomic ratio increased. Such enhanced reduction may be attributed to the strong $\mathrm{Co}-\mathrm{Cu}$ interaction originated from the intimate contact and the good interdispersion of the $\mathrm{CuO}$ and $\mathrm{Co}_{3} \mathrm{O}_{4}$, which possibly leads to a junction of their band levels in the solid solution or the mixed oxidations. ${ }^{54}$ Such strong interactions also have been found for copper-zinc chromite catalysts and $\mathrm{CuO}-\mathrm{ZnO}$ system..$^{55,56}$

\section{Conclusion}

In this work, we have proposed a novel and simple method to prepare Co-based ternary metal oxides $\mathrm{Cu}_{x} \mathrm{Co}_{3-x} \mathrm{O}_{4}$ with cube-like morphology and studied the effect of replacing $\mathrm{Co}^{2+}$ with $\mathrm{Cu}^{2+}$ on the catalytic activity of $\mathrm{Co}_{3} \mathrm{O}_{4}$ towards $\mathrm{CO}$ oxidation. The $\mathrm{Cu}_{x^{-}}$ $\mathrm{Co}_{3-x} \mathrm{O}_{4}$ microcubes with controlled composition were prepared by one step pyrolysis of $\mathrm{Co} / \mathrm{Cu}$-MFFs, in which the $\mathrm{Cu} / \mathrm{Co}$ atomic ratio can be tuned through adjusting the compositions of growth precursor solution. The obtained mesoporous $\mathrm{Cu}_{x} \mathrm{Co}_{3-x} \mathrm{O}_{4}$ have enhanced catalytic properties for $\mathrm{CO}$ oxidation compared to the pure porous $\mathrm{Co}_{3} \mathrm{O}_{4}$ when the atomic ratio of $\mathrm{Cu} / \mathrm{Co}$ is no more than $1 / 2$ in the solution of preparing precursors. The larger specific surface areas and stronger reducibility resulted from the introduced new secondary $\mathrm{Cu}$ metal nodes into $\mathrm{Co} / \mathrm{Cu}-\mathrm{MFFs}$ which may play important roles in improving catalytic performance. We believe that the synthetic strategy can also be extended to obtain other ternary metal oxides with different structures by controlling the morphology and the compositions of the bimetal-formate frameworks, which might have a higher catalytic performance or exhibit excellent properties in other applications.

\section{Conflicts of interest}

There are no conflicts to declare.

\section{Acknowledgements}

Financial supports for this work have been received from Key Laboratory Open Research Foundation of Xinjiang Autonomous Region (No. 2016D03008) and National Natural Science Foundation of China (No. 21661029, 21771157, 21663029).

\section{References}

1 H.-J. Freund, G. Meijer, M. Scheffler, R. Schlögl and M. Wolf, Angew. Chem., Int. Ed., 2011, 50, 10064-10094.

2 M. Haruta, S. Tsubota, T. Kobayashi, H. Kageyama, M. J. Genet and B. Delmon, J. Catal., 1993, 144, 175-192.

3 J.-C. Ding, H.-Y. Li, T.-C. Cao, Z.-X. Cai, X.-X. Wang and X. Guo, Solid State Ionics, 2017, 303, 97-102.

4 K. M. Adams and G. W. Graham, Appl. Catal., B, 2008, 80, 343-352.

5 P. Landon, J. Ferguson, B. E. Solsona, T. Garcia, A. F. Carley, A. A. Herzing, C. J. Kiely, S. E. Golunski and G. J. Hutchings, Chem. Commun., 2005, 3385-3387.

6 J. Lin, X. Wang and T. Zhang, Chin. J. Catal., 2016, 37, 18051813.

7 B. Liu, Y. Liu, H. Hou, Y. Liu, Q. Wang and J. Zhang, Catal. Sci. Technol., 2015, 5, 5139-5152.

8 L. W. Guo, P. P. Du, X. P. Fu, C. Ma, J. Zeng, R. Si, Y. Y. Huang, C. J. Jia, Y. W. Zhang and C. H. Yan, Nat. Commun., 2016, 7, 13481.

9 B. Qiao, J. Lin, A. Wang, Y. Chen, T. Zhang and J. Liu, Chin. J. Catal., 2015, 36, 1505-1511.

10 H. Guan, J. Lin, B. Qiao, X. Yang, L. Li, S. Miao, J. Liu, A. Wang, X. Wang and T. Zhang, Angew. Chem., Int. Ed., 2016, 55, 2820-2824.

11 H. Guan, J. Lin, L. Li, X. Wang and T. Zhang, Appl. Catal., B, 2016, 184, 299-308.

12 I. Langmuir, Trans. Faraday Soc., 1992, 17, 621-654.

13 M. Haruta, N. Yamada, T. Kobayashi and S. Iijima, J. Catal., 1989, 115, 301-309.

14 L. F. Liotta, H. Wu, G. Pantaleo and A. M. Venezia, Catal. Sci. Technol., 2013, 3, 3085-3102.

15 X. Wang, W. Zhong and Y. Li, Catal. Sci. Technol., 2015, 5, 1014-1020.

16 Z. Zhao, X. Lin, R. Jin, G. Wang and T. Muhammad, Appl. Catal., B, 2015, 115-116, 53-62.

17 Y. Su, Z. Tang, W. Han, Y. Song and G. Lu, Catal. Surv. Asia, 2015, 19, 68-77.

18 C. J. Jia, M. Schwickardi, C. Weidenthaler, W. Schmidt, S. Korhonen, B. M. Weckhuysen and F. Schuth, J. Am. Chem. Soc., 2011, 133, 11279-11288.

19 A. Biabani-Ravandi and M. Rezaei, Chem. Eng. J., 2012, 184, 141-146.

20 T. Cwele, N. Mahadevaiah, S. Singh and H. B. Friedrich, Appl. Catal., B, 2016, 182, 1-14.

21 Y. Yu, T. Takei, H. Ohashi, H. He, X. Zhang and M. Haruta, J. Catal., 2009, 267, 121-128.

22 H.-F. Wang, R. Kavanagh, Y.-L. Guo, Y. Guo, G. Lu and P. Hu, J. Catal., 2012, 296, 110-119.

23 X. Xie, Y. Li, Z. Q. Liu, M. Haruta and W. Shen, Nature, 2009, 458, 746-749.

24 J. Jansson, A. E. C. Palmqvist, E. Fridell, M. Skoglundh, L. Österlund, P. Thormählen and V. Langer, J. Catal., 2002, 211, 387-397.

25 P. Broqvist, I. Panas and H. Persson, J. Catal., 2002, 210, 198206. 
26 F. Grillo, M. M. Natile and A. Glisenti, Appl. Catal., B, 2004, 48, 267-274.

27 M. Y. Guo, F. Liu, J. Tsui, A. A. Voskanyan, A. M. C. Ng, A. B. Djurišić, W. K. Chan, K.-Y. Chan, C. Liao, K. Shih and C. Surya, J. Mater. Chem. A, 2015, 3, 3627-3632.

28 R. Zhang, L. Hu, S. Bao, R. Li, L. Gao, R. Li and Q. Chen, J. Mater. Chem. A, 2016, 4, 8412-8420.

29 M. Zhou, L. Cai, M. Bajdich, M. García-Melchor, H. Li, J. He, J. Wilcox, W. Wu, A. Vojvodic and X. Zheng, ACS Catal., 2015, 5, 4485-4491.

30 E. A. Dolgopolova, A. J. Brandt, O. A. Ejegbavwo, A. S. Duke, T. D. Maddumapatabandi, R. P. Galhenage, B. W. Larson, O. G. Reid, S. C. Ammal, A. Heyden, M. Chandrashekhar, V. Stavila, D. A. Chen and N. B. Shustova, J. Am. Chem. Soc., 2017, 139, 5201-5209.

31 L. Chen, R. Luque and Y. Li, Chem. Soc. Rev., 2017, 46, 46144630.

32 X. Yang and Q. Xu, Cryst. Growth Des., 2017, 17, 1450-1455.

33 L. Zhu, X. Q. Liu, H. L. Jiang and L. B. Sun, Chem. Rev., 2017, 117, 8129-8176.

34 F. Wang, X. Wang, D. Liu, J. Zhen, J. Li, Y. Wang and H. Zhang, ACS Appl. Mater. Interfaces, 2017, 6, 22216-22223.

35 Y. Zhu, C. Cao, J. Zhang and X. Xu, J. Mater. Chem. A, 2015, 3, 9556-9564.

36 L. Shen, L. Yu, X.-Y. Yu, X. Zhang and X. W. D. Lou, Angew. Chem., Int. Ed., 2015, 54, 1868-1872.

37 J. Wei, Y. Feng, Y. Liu and Y. Ding, J. Mater. Chem. A, 2015, 3, 22300-22310.

38 L. Han, X.-Y. Yu and X. W. D. Lou, Adv. Mater., 2016, 28, 4601-4605.

39 H. Li, M. Liang, W. Sun and Y. Wang, Adv. Funct. Mater., 2016, 26, 1098-1103.

40 R. R. Salunkhe, Y. V. Kaneti and Y. Yamauchi, ACS Nano, 2017, 11, 5293-5308.

41 Z. Yu, Y. Bai, Y. Liu, S. Zhang, D. Chen, N. Zhang and K. Sun, ACS Appl. Mater. Interfaces, 2017, 9, 31777-31785.
42 S. Zheng, X. Li, B. Yan, Q. Hu, Y. Xu, X. Xiao, H. Xue and H. Pang, Adv. Energy Mater., 2017, 7, 1602733.

43 Z. Wang, K. Hu, S. Gao and H. Kobayashi, Adv. Mater., 2010, 22, 1526-1533.

44 L. C. Gomez-Aguirre, B. Pato-Doldan, J. Mira, S. CastroGarcia, M. A. Senaris-Rodriguez, M. Sanchez-Andujar, J. Singleton and V. S. Zapf, J. Am. Chem. Soc., 2016, 138, 1122-1125.

45 B. Pato-Doldan, L. C. Gomez-Aguirre, A. P. Hansen, J. Mira, S. Castro-Garcia, M. Sanchez-Andujar, M. A. SenarisRodriguez, V. S. Zapf and J. Singleton, J. Mater. Chem. C, 2016, 4, 11164-11172.

46 X. Huang and N. Zheng, J. Am. Chem. Soc., 2009, 131, 46024603.

47 J. Yin, J. Wang, M. Li, C. Jin and T. Zhang, Chem. Mater., 2012, 24, 2645-2654.

48 Y. Xie, F. Dong, S. Heinbuch, J. J. Rocca and E. R. Bernstein, Phys. Chem. Chem. Phys., 2010, 12, 947-959.

49 A. Alvarez, S. Ivanova, M. A. Centeno and J. A. Odriozola, Appl. Catal., A, 2012, 431-432, 9-17.

50 G. Li, L. Li, Y. Li and J. Shi, New J. Chem., 2015, 39, 17421748.

51 J. Zhu and Q. Gao, Microporous Mesoporous Mater., 2009, 124, 144-152.

52 C. Zhang, L. Zhang, G.-C. Xu, X. Ma, Y.-H. Li, C.-Y. Zhang and D.-Z. Jia, New J. Chem., 2017, 41, 1631-1636.

53 J.-Y. Luo, M. Meng, X. Li, X.-G. Li, Y.-Q. Zha, T.-D. Hu, Y.-N. Xie and J. Zhang, J. Catal., 2008, 254, 310-324.

54 G. Fierro, M. Lo Jacono, M. Inversi, R. Dragone and P. Porta, Top. Catal., 2000, 10, 39-48.

55 G. L. Castiglioni, A. Vaccari, G. Fierro, M. Inversi, M. Lo Jacono, G. Minelli, I. Pettiti, P. Porta and M. Gazzano, Appl. Catal., A, 1995, 123, 123-144.

56 G. Fierro, M. Lo Jacono, M. Inversi, P. Porta, F. Cioci and R. Lavecchia, Appl. Catal., A, 1996, 137, 327-348. 